\title{
Epigenetic drugs
}

Recent patents for pharmaceutical compounds comprising and treatments using histone deacetylase and DNA methyltransferase inhibitors.

\begin{tabular}{|c|c|c|c|c|}
\hline Patent number & Description & Assignee & Inventor & Date \\
\hline US $10,576,066$ & $\begin{array}{l}\text { A method for modulating programmed death receptor ligand } \\
1 \text { (PDL1) in a cancer cell, comprising contacting the cell with a } \\
\text { composition comprising a histone deacetylase (HDAC) inhibitor. } \\
\text { Also, a method for treating a tumor in a subject, comprising } \\
\text { administering to the subject a therapeutically effective } \\
\text { amount of a composition comprising a HDAC inhibitor and a } \\
\text { composition comprising a therapeutically effective amount of } \\
\text { a PDL1 inhibitor, a programmed death } 1 \text { receptor inhibitor, or a } \\
\text { combination thereof. }\end{array}$ & $\begin{array}{l}\text { H. Lee Moffitt Cancer } \\
\text { Center and Research Institute } \\
\text { (Tampa, FL, USA) }\end{array}$ & $\begin{array}{l}\text { Villagra AV, } \\
\text { Sotomayor EM }\end{array}$ & $3 / 3 / 2020$ \\
\hline US $10,544,156$ & $\begin{array}{l}\text { A compound or a pharmaceutically acceptable salt or solvate } \\
\text { thereof as well as a pharmaceutical composition containing } \\
\text { such a compound, and the use of such a compound as a drug, } \\
\text { notably as a DNA methyltransferase inhibitor, in particular in } \\
\text { the treatment of cancer. }\end{array}$ & $\begin{array}{l}\text { Pierre Fabre Medicament } \\
\text { (Boulogne-Billancourt, France), } \\
\text { Centre National de la Recherche } \\
\text { Scientifique (Paris) }\end{array}$ & $\begin{array}{l}\text { Halby L, Menon } \mathrm{Y} \text {, } \\
\text { Kaloun } \mathrm{EB} \text {, Long } \mathrm{C} \text {, } \\
\text { Arimondo } \mathrm{PB}\end{array}$ & $1 / 28 / 2020$ \\
\hline US $10,537,535$ & $\begin{array}{l}\text { Compounds that act as HDAC inhibitors and can affect } \\
\text { expression of genes in vivo and in vitro. Such inhibitors can be } \\
\text { used as therapeutics for numerous disease conditions, such as } \\
\text { a variety of cancers, neural degenerative diseases, neurological } \\
\text { diseases, senescence and infectious diseases. }\end{array}$ & $\begin{array}{l}\text { The Regents of the University of } \\
\text { California (Oakland, CA, USA) }\end{array}$ & Ray A, Yamanaka S & $1 / 21 / 2020$ \\
\hline US $10,538,498$ & $\begin{array}{l}\text { Novel compounds having HDAC6 inhibitory activity, } \\
\text { stereoisomers thereof or pharmaceutically acceptable salts } \\
\text { thereof, the use thereof for the preparation of therapeutic } \\
\text { medicaments, pharmaceutical compositions containing the } \\
\text { same, a method for treating diseases using the composition, } \\
\text { and methods for preparing the novel compounds. }\end{array}$ & $\begin{array}{l}\text { Chong Kun Dang Pharmaceutical } \\
\text { (Seoul) }\end{array}$ & $\begin{array}{l}\text { Lee J, Han Y, } \\
\text { Kim Y, Choi D, } \\
\text { Min J, Bae M, } \\
\text { Yang H, Kim D }\end{array}$ & $1 / 21 / 2020$ \\
\hline US $10,532,053$ & $\begin{array}{l}\text { A 4-arylamino quinazoline hydroxamic acid compound } \\
\text { having a HDAC inhibitory activity, preparation method of } \\
\text { the compound, pharmaceutical composition comprising the } \\
\text { compound, and use of the compound and the pharmaceutical } \\
\text { composition in the preparation of a HDAC inhibitor medicine. }\end{array}$ & $\begin{array}{l}\text { Guangdong Zhongsheng } \\
\text { Pharmaceutical (Guangdong, } \\
\text { China) }\end{array}$ & $\begin{array}{l}\text { Chen L, Long C, } \\
\text { Chen X, Liu Z, } \\
\text { Ye H, Xie C }\end{array}$ & $1 / 14 / 2020$ \\
\hline US $10,533,003$ & Polyheteroaryl HDAC inhibitors. & $\begin{array}{l}\text { Karus Therapeutics } \\
\text { (Oxfordshire, UK) }\end{array}$ & $\begin{array}{l}\text { Shuttleworth } \\
\text { SJ, Cecil AR, } \\
\text { MacCormick S, } \\
\text { Nodes WJ, } \\
\text { Tomassi CD, } \\
\text { Silva FA }\end{array}$ & $1 / 14 / 2020$ \\
\hline US $10,519,149$ & $\begin{array}{l}\text { Compounds and pharmaceutically acceptable salts thereof, } \\
\text { and pharmaceutical compositions thereof, that are useful in the } \\
\text { treatment of conditions associated with inhibition of histone } \\
\text { deacetylase (e.g., HDAC2). }\end{array}$ & Rodin Therapeutics (Boston) & $\begin{array}{l}\text { Fuller NO, } \\
\text { Lowe JA III }\end{array}$ & $12 / 31 / 2019$ \\
\hline US $10,508,122$ & $\begin{array}{l}\text { Novel hydroxamic acids that are specific HDAC inhibitors } \\
\text { and/or TTK/Mps1 kinase inhibitors, including pharmaceutically } \\
\text { acceptable salts thereof, that are useful for modulating } \\
\text { HDAC and/or TTK/Mps1 kinase activity, pharmaceutical } \\
\text { compositions comprising these compounds, and processes } \\
\text { for their preparation. }\end{array}$ & $\begin{array}{l}\text { The Regents of the University of } \\
\text { Colorado (Denver) }\end{array}$ & $\begin{array}{l}\text { Liu X, Zhang G, } \\
\text { Chan DC-F, } \\
\text { Piscopio AD }\end{array}$ & $12 / 17 / 2019$ \\
\hline
\end{tabular}

Source: United States Patent and Trademark Office (http://www.uspto.gov).

Published online: 11 May 2020

https://doi.org/10.1038/s41587-020-0523-2 